\title{
8. The Future of Northeast Asia's Institutional Architecture
}

Vinod K. Aggarwal, University of California, Berkeley

Min Gyo Koo, Yonsei University

Seungjoo Lee, Chung-Ang University

\subsection{Introduction 1}

This volume has focused on how and to what extent the triple post shocks-namely the post-Cold War, the post-Asian financial crisis of 1997-98, and the post-September 11, 2001 attacks-have helped Northeast Asian countries secure inclusive club goods to realize free trade, financial stability, and collective security. The emerging institutional architecture in Northeast Asia has been marked by the proliferation of free trade agreements (FTAs), preferential financial arrangements, and both formal and informal security dialogues.

The institutional architecture under the San Francisco system served Northeast Asia well for the Cold War period, obviating the need for any significant regional institutionalization of both economic and security affairs. In the hub-and-spokes network of the San Francisco system, the U.S. served not only as the principal architect of regional order, but also as a power balancer between Japan and China, as well as between the two Koreas and the two Chinas. U.S. hegemony also played a critical role in gluing together its key allies through open access to its market, thus creating a unique institutional mix of bilateralism and multilateralism.

\footnotetext{
${ }^{1}$ We are deeply indebted to Jonathan Chow, Edward Fogarty, and Kristi Govella for their comments and editorial assistance.
} 
More recently, however, the traditional institutional equilibrium in Northeast Asia has come under heavy strain. The changes are subtle but significant in both the economic and security issue areas. Although Northeast Asian countries continue to pay lip service to their commitment to global economic institutions such as the World Trade Organization (WTO) and the International Monetary Fund (IMF), the erosion of their confidence in such global multilateral mechanisms is clearly visible in the proliferation of FTAs and currency swap agreements. ${ }^{2}$ In the security issue area, there have emerged various official and unofficial, formal and informal, bilateral and minilateral dialogues to resolve regional security imperatives, ranging from the rise of China, the Taiwan Strait issue, and the North Korean nuclear crisis. Although the strength and effectiveness of these security fora remain uncertain, the increasing number of channels for security dialogue and negotiations indicate positive and dynamic processes of promoting regional peace and stability. ${ }^{3}$

This concluding chapter proceeds as follows. Section 8.2 summarizes our theoretical arguments. To systematically analyze the evolution of new institutional architecture in Northeast Asia, we developed an institutional bargaining game framework, focusing on the interplay of four broadly defined causal elements-namely initial shocks, goods, individual bargaining situations, and the existing institutional context. Based upon this conceptual framework, Section 8.3 analyzes the evolution of national strategies vis-à-vis the emerging regional institutional order, while summarizing key findings of country case chapters on South Korea, China, Japan, North Korea, Russia, and the U.S. Finally, Section 8.4 highlights the nexus between economics and security and draws policy implications for the future of economic and security institution building in Northeast Asia.

\footnotetext{
2 Aggarwal and Koo 2005a; Pempel 2005; Aggarwal and Urata 2006; and Solis and Katada 2007.

${ }^{3}$ Evans and Fukushima 1999; Buzan 2003; Job 2003; Prichard 2004; and Bullock 2005.
} 


\subsection{An Institutional Bargaining Game Approach: Initial Shocks, Goods, Individual Bargaining Situations, and Institutional Fit}

The process of a shift from an initial institutional equilibrium to a new one generally comes about with some initial shocks that create pressure for change. Initial shocks may stimulate or impede the supply of certain types of goods that pertain to either economics or security, or both. While there are many factors that might affect national responses to initial shocks and subsequent change in the provision of goods, the most significant elements are countries' individual bargaining situations, consisting of their international position, domestic power structures, and elite beliefs. Finally, if countries choose to create new regional institutions or modify existing ones, they must decide on whether and to what extent those institutions are to be influenced by the context of global multilateral institutions. In this section, we briefly summarize the key arguments of our institutional bargaining game approach.

\subsubsection{Initial Shocks}

At the outset of the Cold War, the San Francisco system put Northeast Asian countries on a unique institutional path consisting of bilateralism and multilateralism in both economic and security issue areas. The San Francisco system offered America's Northeast Asian allies access to the U.S. market in return for hub-and-spokes alliances. At the same time, U.S. allies were encouraged to participate in globally-focused multilateral fora such as the WTO, the IMF, and the UN. Aside from informal networks based on corporate and ethnic ties, the San Francisco system created few incentives for Northeast Asian countries to develop exclusive regional economic and security arrangements. ${ }^{4}$ Yet, the pressure for a shift from traditional to new institutional equilibrium has come about through three major initial shocks: the end of the Cold War, the Asian financial crisis, and the September 11 attacks.

First, the post-Cold War shock in the early 1990s produced an outpouring of proposals aimed at developing economic regionalism in Northeast Asia. However, the contribution of the end of the Cold

\footnotetext{
${ }^{4}$ Calder 2004; and Katzenstein 1997.
} 
War to Northeast Asia was more visible in the security issue area, as seen in the Nakayama proposal, the operation of the Korean Peninsula Energy Development Organization (KEDO), and the establishment of the ASEAN Regional Forum (ARF) as well as a series of Track Two initiatives.

The second turning point came in the wake of the Asian financial crisis of 1997-98. The financial crisis revealed a number of shared weaknesses among Northeast Asian economies. Concurrently, Northeast Asian countries' commitment to a broad-based, multilateral trade and financial regime eroded significantly. Recognizing that tighter institutionalization of intraregional commercial and financial ties might be a better commitment mechanism for providing economic security, Northeast Asian countries began to weave a web of preferential economic arrangements.

The latest turning point for the institutional order in Northeast Asia came with the September 11, 2001 terrorist attacks. The American global war on terror and America's subsequent departure from its conventional emphasis on bilateral security ties under the San Francisco system have brought about fundamental shifts in Northeast Asia's balance of power politics. As seen in the current Six-Party Talks process to deal with the North Korean nuclear issue, many regional experts became more hopeful about the possibility of a more formal organizational framework for minilateral security cooperation in Northeast Asia.

\subsubsection{Goods}

In dealing with the emerging institutional architecture, we focus on the three most prominent goals of institutional cooperation: trade liberalization, financial stability, and regional security. We assume that the provision of these goals may take on four different types of goods depending on the degree of rivalry and excludability: private goods, club goods, common pool resources, and public goods.

In terms of goods, Northeast Asia's new appetite for preferential economic arrangements and regional security dialogues reflects a convergence of interests in securing inclusive club goods in the face of growing economic and security uncertainties. Put differently, the political initiatives and intrinsic interest in creating regional eco- 
nomic and security arrangements reflect the growing need for an insurance policy to realize free trade, financial stability, and regional security when traditional mechanisms under the San Francisco system stall or dismantle steadily in the post-triple period.

More specifically, with traditional mechanisms within the WTO offering no salient solutions, Northeast Asian countries quickly turned toward FTAs to assure a market for their products. Currently, the stalemated Doha Development Round of WTO talks add greater enthusiasm to Northeast Asian countries' turn toward FTAs.

In the financial issue area, a conspiracy theory still haunts many East Asians that the U.S. was behind the Asia-bashing and severe austerity programs imposed by the IMF in the middle of the financial crisis. East Asian countries' deepening distrust of global public goods exclusively provided by the IMF has thus motivated them to establish their own regional financial mechanisms such as the Chiang Mai Initiative (CMI) and Asian Bond Market Initiative (ABMI). The ASEAN Plus Three (APT) mechanism has proven effective in promoting financial cooperation in recent years.

Finally, although the web of bilateral security alliances under the San Francisco system will not come to an end anytime soon, the traditional approach to the provision of regional security as a bilateral club good is increasingly incapable of meeting new collective security needs. As will be discussed shortly, the rise of China and the relative decline of U.S. hegemony are the main causes. As such, Northeast Asian countries are now considering a variety of regional alternatives, among which the Six-Party Talks process offers a prototype of a collective mechanism to deal with common regional security problems, departing from traditional reliance on bilateral mechanisms led by the U.S.

\subsubsection{Individual Bargaining Situations}

Among the most significant elements that determine national responses to external shocks and the changes in the provision of goods, we focused on three sets of broadly defined elements as causal variables: (1) an actor's relative position within the international distribution of capabilities; (2) domestic power structures that 
reflect coalitions and political regime type; and (3) elite beliefs and ideas about issue linkages.

In Northeast Asia, two aspects of the shifting international context have been the basis for exploring institutional cooperation in trade, finance, and security. The first factor is the relative decline of the U.S. in both economic and security affairs in Northeast Asia. The second factor concerns the rise of China along the international continuum of economic and strategic development. As Kun-Chin Lin notes in this volume, it may be too early to determine whether China's strategic shift has created a regional dynamic in favor of an anti-U.S. institutional equilibrium. Notwithstanding, the combination of these two strategic developments has brought about significant changes in Northeast Asian balance of power politics, thus undermining the San Francisco system and encouraging the development of an alternative mechanism for economic and security cooperation.

Concurrently, political developments at the national level have altered the economic and security payoffs confronting individual countries as many, if not all, Northeast Asian countries move toward liberalization, rendering cooperative outcomes at the regional level more likely and the requirements of institution-building less daunting. But equally important, as Northeast Asian countries move from authoritarianism toward greater political pluralism, the twin challenges of responding to nationalist sentiments and maintaining political legitimacy may constrain their political leeway to deal with complex economic and security interdependence and institutionbuilding processes.

As both international and national variables have negative, as well as positive, impacts on institutionalization, materially-focused variables alone cannot determine the likely institutional outcomes in Northeast Asia. The direction of change and how it is to be achieved really depend on elite beliefs and ideas about the causal connections among issues and the need to handle problems on a multilateral, minilateral, bilateral, and/or unilateral basis. In this context, there is a strong indication of new ideational formulas that support regional alternatives for economic and security cooperation. Such ideational and perceptional changes will provide Northeast Asian countries with the basic conditions for improving their relationship in the long 
run and lay the groundwork for a potentially robust regional institutional architecture.

\subsubsection{Institutional Fit}

Our institutional bargaining game approach posits that as countries attempt to meet their trade, financial, and security needs in a new environment, they often negotiate the number of participants, geographic coverage, scope and strength of new arrangements, or modify existing ones. At the same time, they strategically interact with each other within the context of broader institutional arrangements such as the WTO, the IMF, and the UN. To this point, Northeast Asia's new appetite for FTAs is geographically open with a focus on both intra- and extra-regional arrangements. Also, many of these agreements attempt to cover broader areas and elements beyond trade. This indicates that these FTAs are WTO-plus or an attempt at institutional division of labor.

In the financial issue area, Northeast Asia's nascent but promising efforts at institutionalizing its financial and monetary relations revolve around a more exclusively "Asia"- focused institutions such as the CMI, the ABMI, the Asian Currency Unit (ACU), and the Asian Monetary Fund (AMF). These regional efforts might implicitly challenge the IMF-centered U.S. dollar-based financial system, but there is an equally strong possibility that they will be soundly nested within global institutions.

In Northeast Asia, the geographic scope of regional security dialogues is mixed. Some prominent examples-such as the ARF, the Council on Security Cooperation in the Asia-Pacific (CSCAP), and the Northeast Asian Cooperation Dialogue (NEACD) - have broadbased membership that extends beyond the geography of Northeast Asia, although Northeast Asian membership outweighs its nonAsian counterpart in terms of political significance, with the exception of the U.S. Despite potential tensions stemming from the shifting global and regional balance of power, the goals and operations of these institutions have largely been compatible with U.S.designed global security architecture thus far. 


\subsection{Cross-national Developments}

In their analysis of evolutionary dynamics in South Korea's regional strategy in Chapter 2, Seungjoo Lee and Chung-in Moon find that South Korea's survival strategy-centered on its bilateral security alliance with the U.S. and active participation in GATT-led trade liberalization-largely remained intact until the early days of the post-Cold War period. Even when it embraced regionalism, South Korea preferred regional arrangements with multilateral character as much as possible. South Korea's institutional choice of APEC is a prime example.

Lee and Moon argue, however, that the outbreak of the Asian financial crisis spurred South Korea to critically re-evaluate its traditional foreign economic policy. The (mis-) management of the crisis by the U.S and the IMF and APEC's inability to supply a regional solution to the crisis combined to raise South Korea's interest in creating regional cooperative mechanisms. Two major policy initiatives under the Kim Dae-jung government were APT and FTAs. Perceiving APT as a useful venue for South Korea to project its own regional visions, the Kim government played a pivotal role in establishing the East Asia Vision Group (EAVG) and the East Asia Study Group (EASG). FTAs provided another alternative for South Korean policymakers. Interestingly, before it started negotiations with foreign governments, the Kim government embarked on organizational reform to streamline bureaucratic coordination for foreign economic policymaking that ultimately led to the creation of the Office of the Minister for Trade (OMT).

South Korea's regional policy took another turn as Roh Moo-hyun came to power in the aftermath of 9/11. By unveiling an ambitious regional plan, the Northeast Asian Cooperation Initiative (NEACI), the Roh government hoped to build a regional community of mutual trust, reciprocity, and symbiosis. Although the NEACI's narrow geographical focus on Northeast Asia may be viewed as a break from South Korea's traditional regional policy, Lee and Moon contend that its main thrust is to contribute to regional and global peace and prosperity by settling tensions and problems in the proximate region. 
Lee and Moon also argue that as it became obvious that the NEACI had not produced expected outcomes, the Roh government gradually turned to FTAs as an alternative. What is noteworthy in South Korea's FTA strategies is that the Roh government somewhat surprisingly embarked on the Korea-U.S. (KORUS) FTA negotiations when the chances for a trilateral FTA among South Korea, China, and Japan were slim. Lee and Moon stress that the Roh government made an early push for the KORUS FTA in order to improve economic ties as well as overall diplomatic and security relations between Seoul and Washington. In short, they argue that South Korea's FTA strategy has turned more proactive under the Roh government, in stark contrast to the reactive approach taken by the Kim Dae-jung government.

In the analysis of China's evolving regional strategies presented in Chapter 3, Kun-Chin Lin finds that China skillfully took advantage of the triple shocks to establish itself as a pacifist actor in the region. In the aftermath of the Asian financial crisis, explains Lin, a China that had traditionally lent lukewarm support to regional institutionalization began to project its own regional visions. As it did not fall victim to the Asian financial crisis, China with boosted confidence ambitiously promoted various regional schemes not just in the economic arena (ASEAN Plus Three), but also in security areas (the Shanghai Cooperation Organization).

Lin argues that 9/11 provided China with another golden opportunity to consolidate its regional strategies. On the one hand, China exploited U.S. preoccupation with Iraq and Afghanistan to find a niche role in the regional institutionalization. On the other hand, acknowledging U.S. leadership in the region, China endeavors to assure its neighbors that its rise will not hamper the existing order in the region, but generate overall welfare gains. Lin concludes that the doctrine of "peaceful rise" aptly characterizes China's sensible approach to institutionalization in Northeast Asia.

In Chapter 4, Saori Katada and Mireya Solis examine Japanese regional economic policy in the post-Cold War period, finding that two of the triple shocks - the end of the Cold War and the Asian financial crisis-were particularly crucial in driving Japan's regional policy into a new direction. First, they argue that the end of the Cold War presented the Japanese government with a formidable challenge 
in formulating its regional policy: how to deal with the rise of China when the U.S. commitment to East Asian security seemed to be declining. In their view, concern about the Sino-Japanese rivalry motivated Japan to play an active role in regional institution building because Japan found it necessary to "lock in" institutions before the balance of power between the two countries could swing in favor of the latter.

Second, Katada and Solis contend that the Asian financial crisis, which revealed starkly different perceptions about the nature of the crisis between the US (and IMF) and Japan (and other East Asian countries), also catalyzed Japan to seek regional institutionalization in the economic arena as an effective means to preempt another potential crisis. The crisis also revealed Japan's frustration with an APEC that was initially founded on the principle of open regionalism. Fissures began to grow between the Japanese voluntaristic and informal approach and the U.S. legalistic approach to trade liberalization. It was against this backdrop that Japan turned to bilateral FTAs. With FTAs, argue Katada and Solis, Japan sought to gain much more control over the pace and scope of liberalization. They also point out that whereas Japan's embrace of FTAs indeed signifies an important policy shift, its FTA strategies are constrained by domestic politics as well as regional factors. First, squeezed between internationally competitive export-oriented businesses and a heavily protected agricultural sector, the Japanese government was forced to launch FTA negotiations primarily with small economies and exclude politically sensitive items. Second, concerned about China's hub-and-spoke strategy, Japan had to speed up its FTA negotiations with Southeast Asian countries. Such competitive dynamics between the two countries, to significant degrees, pushed Japan to seek FTA strategies tilted toward forming rivaling hub-and-spoke FTA networks rather than a region-wide trade bloc.

Finally, Katada and Solis explain why, in contrast to its gradual approach to trade institution building, Japan took a more significant role in constructing regional monetary and financial institutions. In their view, the sectoral difference derives from a variety of factors: the main sources of policy change in the respective issue area; conflicting interests and mutual distrust between Japan and China; and the reaction of the US. As a result, they conclude that although they 
are still in a nascent stage, Japanese efforts at building financial institutions in East Asia have produced a more tangible outcome.

In Chapter 5, Sang-young Rhyu examines how throughout the post-Cold War period North Korea has attempted to break out of its decades-long isolation to engage in the regionalization process in Northeast Asia. Rhyu observes that the disintegration of the Soviet bloc posed a devastating threat to the Kim Il-sung regime, as its relationship with Russia and China, two principal supporters of the North Korean regime, turned sour. Ironically, this diplomatic impasse motivated North Korea to take a conciliatory approach toward South Korea, culminating in mutual recognition through the United Nations, reaffirmation of the goal of a nuclear-free Korean Peninsula, and signing of the South-North Basic Agreement. Rhyu argues that this rapprochement in inter-Korean relations in the early postCold War period largely stemmed from North Korean initial attempts to rehabilitate its faltering economy by participating in global institutions and regional networks.

Even economically isolated North Korea was not completely immune to disturbances of the Asian financial crisis, as trade with South Korea, a direct victim of the crisis, fell. From this period, argues Rhyu, North Korea and international financial institutions (the IMF, World Bank, and the ADB) began to search for a potential path toward North Korea's integration with the global economy and regional partners. North Korea's efforts to improve relations with major international economic and financial institutions continued in the 2000s, as demonstrated in its application for membership in the Asian Development Bank in 2001. On the security front as well, North Korea took halting steps toward greater regional security cooperation by joining the ARF.

The 9/11 attacks brought indirect yet negative consequences to North Korea when it was designated as a member of the "axis of evil" by the Bush administration. Under pressure from this new development, North Korea established Special Economic Zones including the Gaeseong Industrial Complex. Rhyu argues that the North Korean regime strove to revive its economy by linking its country to the East Asia market through inter-Korean economic cooperation. However, Rhyu concludes by cautioning that despite North Korea's efforts to participate in East Asian regionalism, the 
prospects for North Korea's real integration into the region are slim without a fundamental resolution to the North Korean nuclear issue.

In his examination of Russia's regional policy in Chapter 6, Taehwan Kim poses an interesting question: Why has Russia under Vladimir Putin made a dramatic shift in its regional policy toward growing assertiveness and vigorous involvement in the region? He answers that this policy shift has to do with fundamental changes in domestic political governance that took place in the midst of regime changes from the Yeltsin and Putin regimes. That is, political transition from Yeltsin's neofeudal governance to Putin's neoabsolutism was crucial in Russia's projection of a neomercantilist strategy into Northeast Asia.

He further argues that the triple shocks were closely intertwined with these domestic governance changes, paving the way for the effects of this policy shift to materialize. First, in the immediate postcold war period, Russia showed signs of inconsistency in its regional policy, as the Yeltsin regime had to succumb to the political and economic interests of the neofeudal coalition, impairing effective and consistent policy coordination. Russia's marginalization in Northeast Asia was inevitable.

Second, explains Kim, the aftermath of the Asian financial crisis turned out to be a critical juncture in Russian politics in that political balance between the Putin regime and major oligarchs radically changed. Badly damaged by the crisis, oligarchs had no alternative but to watch their political power quickly evaporate, while Putin firmly established his political dominance. The near dissolution of the neofeudal coalition and a quick recovery from the crisis gave the Putin regime greater leeway to conduct regional policies in a more centralized manner. With greater confidence, Russia implemented a series of policy initiatives in Northeast Asia, making efforts to improve its bilateral relationships with tradition allies, actively participate in regional economic and security organizations such as ASEAN, ARF, and APEC, and strengthen its Track II diplomacy.

Finally, Kim argues that the Putin regime consolidated its power domestically by skillfully linking the $9 / 11$ attacks and the Chechen war. Subsequently, analyzes Kim, Russia's regional policy began to display "neomercantilist" features, as the country strategically took advantage of its abundant energy resources as bargaining leverage in 
dealing with Northeast Asian countries. Kim argues that Russia could carry out its neomercantilist policy in a coherent manner because Putin successfully installed a neoabsolutist governance system backed by a new political ruling group, siloviki.

In Chapter 7, Ellen Frost and David Kang examine the way in which each of the triple shocks has affected the role of the U.S. in Northeast Asian regionalism. In their view, despite its military prowess and economic vitality, U.S. regional influence has decreased in the post-Cold War period, particularly compared to that of China. Moreover, the passive American policy stance vis-à-vis the Asian financial crisis, strikingly different from its firm commitment to the Mexican crisis, substantially heightened Northeast Asian countries' suspicions that the U.S. was unreliable as an extraregional. Finally, while the 9/11 incident increased U.S. incentives for military cooperation with Northeast Asian countries to cope with new security threats, the excessive American focus on North Korean nuclear issues again created a perception among Northeast Asian countries that the region did not hold high priority on U.S. policy agenda.

On the future of Northeast Asian regionalism, Frost and Kang find that the prospects for institutionalization in Northeast Asia are not bright. For example, the track record in the security area shows that regional institutions such as the Six-Party Talks and the ASEAN Regional Forum have resulted in limited success at best. On the economic front as well, despite high-level economic integration, institutional arrangements were formed primarily on a bilateral basis. However, on the positive side, the authors caution that it would be premature to underestimate Northeast Asia's potential for institutionalization, because Northeast Asian countries have cultivated institutional foundations in their own way. They argue that in Northeast Asia, "soft" institutionalization based on the principles of dialogue, community-building, and the peaceful resolution of disputes have already produced some meaningful successes in resolving and coordinating sensitive regional issues. 


\subsection{The Future of Economic and Security Institution Building in Northeast Asia}

The traditional institutional order in Northeast Asia has come under heavy strain in light of the triple post shocks. The abrupt end of the Cold War bipolarity, which had acted as the source of regional reluctance to institutionalize economic and security relations, has made it politically easier for Northeast Asian countries to consider institutionalizing their ties. The Asian financial crisis of 1997-98 clearly revealed a number of institutional weaknesses that Northeast Asian economies shared. The September 11 terrorist attacks, and the subsequent American war on global terrorism, have called into question the fate of the Northeast Asian balance-of-power system, which in turn has created additional incentives for Northeast Asian countries to cope with growing economic and security uncertainties through institutional mechanisms.

In view of these triple post shocks, Northeast Asian countries' growing preferences for "club goods"- as opposed to public or private goods-are at the heart of Northeast Asia's drive for a new institutional architecture. As this volume has argued, the triple post shocks have altered the supply of trade liberalization, financial stability, and national security from de facto public goods under the San Francisco system to de jure club goods.

In an effort to understand the shifting institutional dynamics, we have examined countries' individual bargaining situations, focusing on their international strategic and economic interests, domestic power dynamics, and elite beliefs about the value of pursuing regional alternatives. We also showed how the changing nature of broader institutions interacted with country characteristics to alter institutional payoffs in the region.

In view of the tremendous political and economic uncertainties in the contemporary period, the path to deeper and wider economic and security integration in Northeast Asia is likely to be complex. Despite enormous complexities and uncertainties, however, we are sure about one thing: Northeast Asia will remain an open region due to 
its economic and security links to global politics and economies, particularly to those with the U.S. ${ }^{5}$

Yet in the face of the triple post shocks and the resultant changes in Northeast Asian countries' preferences for different types of goods, it is more useful to explore the conditions under which new institutional mechanisms are likely to evolve into broader accords and those under which they might lead to "pernicious" regionalism that undermines global institutions by failing to be firmly nested in the global regime.

Using the institutional map developed and applied in this volume, we can construct simplified scenarios of possible institutional paths that Northeast Asia is likely to take. For us, the openness of Northeast Asian regionalism primarily depends on the following causal variables: (1) the strength of global institutions such as the WTO, the IMF, and the UN in their respective areas; (2) the Sino-Japanese relationship; (3) economic complementarity among countries; and (4) the "balance of interests" between the U.S. and the EU concerning Northeast Asia as their economic and security partner region. ${ }^{6}$

With respect to trade liberalization, the weakness of the WTO opens up institutional space for Northeast Asian trade fora by affecting the provision of public goods and thus the incentives for club goods. In a similar vein, the eroding confidence of Northeast Asian countries in the IMF-centered U.S. dollar-based financial system has motivated them to seek alternative regional club goods such as the CMI, the ABMI, the ACU, and the AMF. Finally, the erosion of America's military commitment to Northeast Asia in the post-triple period has made everyone in the region scramble in search of alternative security mechanisms. In a nutshell, many of their future developments depend on the possibility of a tripartite entente among the U.S., China and Japan, and the resolution of the North Korean issue in both economic and security terms.

If China and Japan reach a political alliance, the formation of a strong Northeast Asian Free Trade Agreement (NEAFTA) is highly likely. If economic complementarities exist among member countries, they will broaden the scope of product coverage; otherwise, we can expect a strong but narrow (or sectoral) NEAFTA. By contrast,

\footnotetext{
${ }^{5}$ Among others, see Katzenstein 2005.

${ }^{6}$ See Aggarwal and Koo 2005b.
} 
if there is no alliance between China and Japan, a NEAFTA is not a possibility.

Certainly Northeast Asia, and more broadly East Asia, will remain an open region, if either the U.S. or the EU, or both, maintain(s) a strong focus on the region. However, if the U.S. continues its focus on the Free Trade Area of the Americas (FTAA) and the EU continues on an eastward and possibly southward expansion path, others may feel excluded. Under these circumstances, the decade-long perception between Northeast and Southeast Asians that Western regional arrangements are forming against them may well rekindle the Mahathir-promoted notion of an exclusive East Asian bloc-be it the East Asia Summit or ASEAN Plus Three (or Plus Six)—or a new China-centered regional hierarchy.

Although it is easy to dismiss the talk in Asia of ASEAN Plus Three (which includes Japan, South Korea, and China) versus ASEAN Plus Six (which also further incorporates Australia, New Zealand, and India), the November 2006 announcement that the U.S. would like to promote a Free Trade Agreement of the Asia-Pacific (FTAAP) suggests that these new efforts to promote Asian regionalism, on the one hand, and the rise of China, on the other, are garnering concern among policymakers in Washington.

We believe that regional institutions are becoming viable means for creating norms and rules of interstate behavior that are essential for establishing regional institutional architecture to manage collective trade, financial, and security issues, the process of which could possibly take at least a few decades, if not centuries. However, we do not claim by any means that we are sure about the future directions of Northeast Asian economic and security regionalism. Rather, we believe that systematic exploration of key variables and their impact in the context of the design of institutions may be better in providing us with more precise, albeit contingent, outcomes.

\section{References}

Aggarwal Vinod, K. and Shujiro Urata, eds. 2006. Bilateral Trade Arrangements in the Asia-Pacific: Origins, Evolution, and Implications. New York: Routledge. 
Aggarwal, Vinod K. and Min Gyo Koo. 2005a. Beyond Network Power? The Dynamics of Formal Economic Integration in Northeast Asia. The Pacific Review 18 (2):189-216.

. 2005b. The Evolution of APEC and ASEM: Implications of the New East Asian Bilateralism. European Journal of East Asian Studies 4 (2):233-261.

Bullock, Todd. 2005. U.S. Hopes Six-Party Talks Can be Model for Northeast Asia: State's Hill says Talks on North Korea's Weapons Programs Strengthen Ties. Washington D.C.: The Washington File, U.S. Department of State.

Buzan Barry. 2003. Security Architecture in Asia: The Interplay of Regional and Global Levels. The Pacific Review 16 (2):143-173.

Calder, Kent E. 2004. Securing Security through Prosperity: The San Francisco System in Comparative Perspective. The Pacific Review 17 (1):135-157.

Evans, Paul and Akiko Fukushima. 1999. Northeast Asia's Future Security Framework: Beyond Bilateralism? Tokyo, Japan: National Institute for Research Advancement. Available from <http://www.nira.go.jp/publ/review/99summer/evans.html>.

Job, Brian. 2003. Track Two Diplomacy: Ideational Contribution to the Evolving Asia Security Order. In Asian Security Order: Instrumental and Normative Features, edited by Muthiah Alagappa. Stanford, Calif.: Stanford University Press.

Katzenstein, Peter J. 1997. Introduction: Asian regionalism in comparative perspective. In Network power: Japan and Asia, edited by Peter Katzenstein and Takashi Shiraishi. Ithaca, New York: Cornell University Press.

- 2005. A World of Regions: Asia and Europe in the American Imperium. Ithaca, New York: Cornell University Press.

Pempel TJ, ed. 2005. Remapping East Asia: The Construction of a Region. Ithaca, New York: Cornell University Press.

Pritchard, Jack. (2004) Beyond Six Party Talks: An Opportunity to Establish a Frame-Work for Multilateral Cooperation in the North Pacific. Paper presented at the Hokkaido Conference for North Pacific Issues, October, .Hokkai Gakuen University,

Solis, Mireya and Saori Katada. 2007. Understanding East Asian CrossRegionalism: An Analytical Framework. Pacific Affairs 80 (2):229-258. 